\title{
RECENT EVOLUTION OF GLACIERS IN COCUY-GÜICAN MOUNTAINS (COLOMBIAN ANDES) AND THEIR HYDROLOGICAL IMPLICATIONS
}

\author{
Juan Ignacio López-Moreno ${ }^{1}$, Francisco Rojas-Heredia ${ }^{1}$, Jorge Luis Ceballos $^{2}$, Enrique \\ Moran $^{3}$, Esteban Alonso ${ }^{4}$, Ixeia Vidaller ${ }^{1}$, Cesar Deschamps-Berger ${ }^{1}$, and Jesús Revuelto ${ }^{1}$ \\ ${ }^{1} \mathrm{CSIC}$ \\ ${ }^{2}$ IDEAM \\ ${ }^{3}$ Universitat de les Illes Balears Facultat de Filsofia i Lletres \\ ${ }^{4} \mathrm{CESBIO}$
}

February 4, 2022

\begin{abstract}
This study updates information on the evolution of glacier shrinkage in Cocuy-Güican mountains since the maximum glacier extent of the Little Ice Age (LIA), and presents the first mass balance data of Ritacuba glacier since 2009, that is compared to the available mass balance for the Conejeras Glacier (Los Nevados National Park). This study also discusses the hydrological significance of Colombian glaciers which is still largely unknown because of the very limited information available. Glaciers in Cocuy-Güican covered $13.2 \mathrm{~km} 2$ in 2019 that compared to the $127.8 \mathrm{~km} 2$ during the maximum LIA represents a shrinkage of 89.7\%. Glacier cover observations in 1955, 1994, 2010 and 2019, reveal that the rate of ice loss was the largest from 1994 to 2010 (0.59 km2 yr-1) and was then more than halved from 2010 to 2019 (0.34 km2 yr-1). This slowdown in glacier retreat is in line with a moderate negative mass balance measured for 2009-2019, with an accumulated loss of 1,766 mm w.e. The progressive confinement of glaciers to higher elevation and optimal topographic context together with a lack of recent marked climatic anomalies, could explain that Cocuy-Güican glaciers have temporally reached near equilibrium state condition. This is in stark contrast with Conejeras glacier where 47,000 mm w.e. has been lost in the same period. The available data on runoff and isotopic traces of streamflows and precipitation suggest a primary control of precipitation on the hydrological variability of the high elevated sites, compared to glacier melt water.
\end{abstract}

\section{Hosted file}

Paper submitted1.doc available at https://authorea.com/users/288838/articles/555360recent-evolution-of-glaciers-in-cocuy-g\%C3\%BCican-mountains-colombian-andes-and-theirhydrological-implications 